\title{
Review
}

\section{Rightlessness in an age of rights: Hannah Arendt and the contemporary struggles of migrants}

\author{
Ayten Gündoğdu \\ Oxford University Press, Oxford, 2015, xii+298pp., ISBN: 978-0199370412
}

Contemporary Political Theory (2017) 16, 269-273. doi:10.1057/cpt.2016.1; advance online publication 26 January 2016

This thoughtful monograph is a major contribution both to the already vast scholarship on Arendt's work and to the theory of the human rights of migrants, especially refugees, asylum seekers and undocumented immigrants. It is a careful study that punctuates theoretical reflections with discussion of legal case studies and concrete examples of rightlessness and of the rightless' activist contestations of them.

Gündoğdu develops a political conception of human rights by drawing on Arendt's work. The human rights framework is not sufficient to redress rightlessness and may even enact or aggravate the rightlessness of particular groups of migrants, despite good intentions (although this is by no means inevitable as many radical critics suspect). Human rights are therefore permanently in need of politics. For Gündoğdu, unlike Rawlsian political theorists of human rights, politics refers less to established institutions than political practices, first and foremost the collective action by the rightless themselves involving 'translation' and (re-)founding human rights and acts of declaration. Gündoğdu's political conception of human rights also helps her to identify trajectories and strategies that are antithetical to their politicization; most notably, the tendency to reduce migrants to suffering bodies that makes them dependent on compassion or turns them into objects of humanitarian administrative rationality and technocracy.

Gündoğdu's contribution to Arendt scholarship is not limited to her engagement with the debate on the famous but enigmatic notion of the 'right to have rights' (Chapter 5), but encompasses Arendt's entire oeuvre. She provides compelling reinterpretations of the notorious social-political distinction (Chapter 2), and of the relative value of labor, work and action (Chapter 4). Finally, Gündoğdu accomplishes a methodological innovation by reconstructing Arendt's 'aporetic approach', providing new insights into the character and implications of the perplexities of human rights that Arendt examined (Chapter 1). Applying such an aporetic inquiry to controversial aspects of Arendt's work itself allows Gündoğdu moreover to 'read Arendt against the grain' (p. 6) fruitfully.

(C) 2016 Macmillan Publishers Ltd. 1470-8914 Contemporary Political Theory Vol. 16, 2, 269-273 www.palgrave.com/journals 
Gündoğdu's guiding concept is 'rightlessness'. Her starting point is Arendt's observation of the paradox of 'the rightlessness of those who appear in their bare humanity' (p. 3) in light of the emergence of statelessness in interwar Europe. Gündoğdu argues that this paradox has not lost much of its currency in our present 'age of rights', although the human rights discourse underwent impressive institutionalizations following WW II. Taking into account developments in international law since the publication of The Origins of Totalitarianism (1951), Gündoğdu does not simply apply Arendt's analysis to present-day concerns. She argues that the predicament of today's refugees, asylum seekers and undocumented immigrants may not be identical to the absolute rightlessness of Arendt's stateless but it is still marked by precarious legal personhood. Although personhood has replaced citizenship as the basis for entitlement to rights, this personhood is quite fragile in the case of particular migrants, as is evident from the proliferation of detention and deportation as routine solutions to the problem of failed asylum seekers and undocumented migrants (Chapter 3). Another indication is the fact that encampment is becoming a protracted condition for ever larger groups of refugees (Chapter 4). Rightlessness for Gündoğdu does not point to mere violations of particular human rights but to a condition (p. 94). Moreover, it is not even merely a legal condition (Chapter 3), but also refers to encroachments of migrants' political and human standing, such as when humanitarian governance deprives refugees of the opportunity to labor and make durable things (Chapter 4). Gündoğdu suggests that if those institutions (including advocacy groups) that strive to further the human rights of migrants do not attend to these non-institutional aspects of rightlessness, they might end up undermining rather than strengthening the legal, political and human status of refugees. For example, refugees may formally have a right to freedom of speech, understood as the right to express oneself without interference. However, without belonging to a political community, those who have nothing left but their 'bare humanity' are rendered aneu logou, speechless.

Gündoğdu's concept of rightlessness is therefore fairly broad. I found it useful on the whole, nonetheless, because it keeps open imaginative or revolutionary appropriations or transformations of human rights beyond existing frameworks. However, sometimes I felt the concept is too wide-ranging because it does not sufficiently allow for differentiations between citizens, non-citizens and second-class citizens. The choice of the term 'migrants' therefore seems quite unfortunate, given the fact that the book is concerned with the political struggles of refugees, asylum seekers and undocumented immigrants.

Gündoğdu demonstrates that the paradox of rightlessness should not be treated as an anomaly to an otherwise well-functioning system of human rights, or as an indication of an implementation deficit. Neither is it the effect of 'hypocritical gestures, or deceptive ploys' (p. 13). Instead, the paradox is symptomatic of fundamental and ultimately irresolvable 'perplexities' or 'aporias' inherent in the 
human rights framework, which strives to relate and hold together principles that are usually considered constitutive and contradictory at the same time (such as the universal and the particular, or the principles of legal equality and national sovereignty and so on) (p. 4). Yet, this observation does not lead Gündoğdu to conclude that dejuridification and dehumanization within (or even through) international law is inevitable, as many radical critics believe. She particularly takes issue with Giorgio Agamben, according to whom there runs a straight line from human rights to sovereign violence. Gündoğdu instead alerts the reader to the contingency and equivocality of the trajectories of human rights norms and institutions: they emerged and developed in particular historical circumstances and may be appropriated in different ways - for better or worse.

Attending to the ambiguity and unpredictability of human rights does not necessarily cause paralysis, as one of Gündoğdu major interlocutors, Jacques Rancière, reproaches Arendt. One of the book's central arguments is that the perplexities entail genuine ethical and political dilemmas that present us with the continuing task of rethinking, reimagining and re-enacting human rights. Hence the significance of the struggles of migrants - be it that ultimately 'the struggle remains undecided', as the title of the conclusion reads. For the Arendtian approach deviates not only from sinister or suspicious skeptical accounts, but also from certain liberal cosmopolitan accounts that are highly institutionalist and blind to the potential adverse consequences of the human rights framework. Gündoğdu reminds scholars associated with the latter of the existence of an 'antinomy between law and institutions' (p. 43), that is, the paradox of law and politics as discussed in recent democratic theory. Likewise, Gündoğdu cautions against taking migrants' struggles for human rights as unequivocal 'success stories heralding the eventual triumph of human rights and postnational citizenship' (p. 188).

Methodologically, this attentiveness to contingency and equivocality matches well with the 'aporetic inquiry' that Gündoğdu develops by drawing from Arendt's presentation of Socrates (Chapter 1). Socratic dialogs are premised on the assumption that everyday concepts give rise to perplexities, as they are based on doxa, opinion and prejudice. Unlike Plato, who considered doxa as false illusions, Arendt's Socrates did not oppose doxa to aletheia, truth, but believed our everyday notions contain elements of truthfulness. This truthfulness of doxai, along with their limits, can only be revealed by close examination and, especially, by 'talking them through' with others. Such inquiry sets the task of critique not as debunking, but as rethinking our entrenched opinions, in order to 'render them meaningful again' (p. 53). One such doxa is the belief that human rights are natural rights. This is not completely false, any more than the opposite belief that human rights are merely historical rights. Gündoğdu also uses this aporetic approach as a strategy for reading Arendt's work itself. For example, she treats Arendt's assumptions about 'the social question' as doxai, in order to 'find out not only what is untenable but also what might be worth affirming' in them (p. 63). 
I will now briefly discuss a number of arguments that I found particularly strong. First, Gündoğdu offers a rereading of Arendt's distinction between the social and the political (Chapter 2). This highly contested distinction has provoked Rancière to reject her account of human rights as useless, too. Gündoğdu takes a performative or practical perspective on the distinction by arguing that it calls forth the need to politicize human rights issues: it requires practices of 'translation' that represent problems as matters of common concern, even, or perhaps particularly, if this involves challenging existing human rights. No issue is a priori exempt from such translation. Most notably, poverty is not a social or a political problem in itself, but may be addressed in either political or anti-political ways. Read this way, the socialpolitical distinction provides a critical tool to identify and challenge practices of depoliticization, in particular humanitarianism. 'Compassionate humanitarianism', humanitarian governance, and military humanitarian intervention reduce rights issues to problems of suffering, which threaten to turn refugees into speechless victims, dependent on others' unreliable affects, such as generosity or charity, and to constrain definitions of human rights to the basic necessities of 'bare humanity'.

Second, Gündoğdu uses a 'critical phenomenology of the human condition' (p. 129) based on a reinterpretation of Arendt's account of the vita activa as a tool to assess refugee camp existence (Chapter 4). Demonstrating that labor, work and action are fundamentally interconnected, Gündoğdu challenges the usual 'action-centric' reading of Arendt's work. I found the revaluation of labor and ordinary life particularly illuminating. By laboring, people not just sustain their organisms, but they also achieve a 'trust in the reality of life' and 'a sense of regularity and familiarity' (p. 128). Their dependency on aid subjects refugees to a condition of physical neediness and 'life alienation' (p. 134). Next, in an interesting section on the value of everyday objects, Gündoğdu demonstrates that accommodation in ramshackle shelters and the prohibition of 'work' (that is, making things) deprives encamped refugees of a durable world. Finally, challenging the view that 'action' in the Arendtian sense is empty because it lacks purpose, Gündoğdu argues that speech in particular is significant for embedding human beings in a political community and humanity. No one would deny that refugees use language, but the structural conditions of encampment deprive them of the opportunity of meaningful speech. The atmosphere of growing distrust replaces speech with the human body as the 'crucial site for claiming rights' (p. 111). Not officials judging asylum seekers' testimonies, but experts increasingly establish the truth about their persecution.

Third, Gündoğdu shifts the debate on the 'right to have rights' between those who seek normative foundations and those who defend the groundlessness of this right (anti-foundationalism) to practices of founding. She proposes to regard human rights declarations as revolutionary new beginnings. Not unlike Jacques Rancière and Bonnie Honig, she points to the political significance of founding public spaces by the rightless themselves, her prime example being the Sans Papiers movement (Chapter 5). The irreducible contingency of every new beginning - such as the lack

272 (c) 2016 Macmillan Publishers Ltd. 1470-8914 Contemporary Political Theory Vol. 16, 2, 269-273 
of formal authorization of declarations in the name of 'We the people' - does not leave founding completely arbitrary, as foundationalists fear. It entails imaginative practices of reenacting and augmenting the principle embodied in prior declarations and may give rise to new rights and rights-bearing subjects. Following Étienne Balibar, Gündoğdu identifies this principle as 'equaliberty'. Being universally valid, equaliberty saves rights declarations from arbitrariness. This is an odd argument, given Gündoğdu's challenge of foundationalism, and not in keeping with Arendt's preference for exemplarity over universal validity.

Gündoğdu's argument that the tendency to reduce refugees to suffering bodies may facilitate rightlessness is one of the book's greatest achievements. Still, I am concerned that the strategy of 'translation' to counter rightlessness unwittingly reproduces the exclusivism Arendt has frequently been charged with, because of its heavy reliance on speech. What about those rightless people who are less articulate than, say, the Sans Papiers protestors? I wish Gündoğdu had pushed her deconstruction of the conventional action-centric - in fact speech-centric - reading of Arendt's political theory further here.

Marieke Borren

University of Pretoria, Pretoria, South Africa marieke.borren@up.ac.za 